\title{
Review \\ Bench-to-bedside review: The value of cardiac biomarkers in the intensive care patient
}

\author{
Anthony S McLean, Stephen J Huang and Mark Salter
}

Department of Intensive Care Medicine, Nepean Hospital, University of Sydney, Sydney, NSW 2750, Australia

Corresponding author: Anthony S McLean, mcleana@med.usyd.edu.au

Published: 2 June 2008

This article is online at http://ccforum.com/content/12/3/215

(c) 2008 BioMed Central Ltd
Critical Care 2008, 12:215 (doi:10.1186/cc6880)

\begin{abstract}
The use of cardiac biomarkers in the intensive care setting is gaining increasing popularity. There are several reasons for this increase: there is now the facility for point-of-care biomarker measurement providing a rapid diagnosis; biomarkers can be used as prognostic tools; biomarkers can be used to guide therapy; and, compared with other methods such as echocardiography, the assays are easier and much more affordable. Two important characteristics of the ideal biomarker are disease specificity and a linear relationship between the serum concentration and disease severity. These characteristics are not present, however, in the majority of biomarkers for cardiac dysfunction currently available. Those clinically useful cardiac biomarkers, which naturally received the most attention, such as troponins and B-type natriuretic peptide, are not as specific as was originally thought. In the intensive care setting, it is important for the user to understand the degree of specificity of these biomarkers and that the interpretation of the results should always be guided by other clinical information. The present review summarizes the available biomarkers for different cardiac conditions. Potential biomarkers under evaluation are also briefly discussed.
\end{abstract}

\section{Introduction}

Nearly $30 \%$ of patients admitted to a general intensive care unit (ICU) have underlying cardiac diseases, and approximately one-half of these $30 \%$ are admitted to the ICU with cardiac problems as the primary cause $[1,2]$. The latter group is mainly comprised of patients with acute myocardial infarction, acute heart failure (HF) or cardiogenic shock. Pulmonary embolism, sepsis-related cardiac dysfunction and arrhythmias are also commonly found in the ICU.

The diagnosis of cardiac problem can be a difficult task in the ICU, partly due to the nonspecificity of clinical signs and symptoms. Prompt treatment can reduce mortality and improve patient outcome, and therefore the value of rapidly identifying the problem and assessment of the condition cannot be understated. Although the introduction of intensive care echocardiography has made the diagnoses easier, diagnoses based on echocardiography alone are not always sufficient and the application requires ready availability of skilled operators [3]. For example, while an enlarged right ventricle denotes pressure or volume overloading, echocardiography sheds little light on the etiology. Proper diagnosis requires the incorporation of various clinical information including medical history, physical examination, electrocardiography, chest X-ray scans and, recently, biomarker levels.

Biomarkers offer certain advantages over other diagnostic tools. First, biomarkers can help clinicians efficiently formulate differential diagnoses. Second, as biomarker levels often correlate with the severity of the disease, they can be used to guide therapy. Third, some of the biomarkers can provide prognostic values. The earliest type of cardiac biomarkers was cardiac enzymes, the uses of which were restricted to the diagnosis of acute myocardial infarction (cardiac necrosis). The discovery of new cardiac biomarkers and the increased sensitivity of the assays have extended the boundary of applications, for example, to the detection of other cardiac pathophysiological processes such as pump failure and right ventricular pressure overload secondary to pulmonary emboli. The present review summarizes the findings of some cardiac biomarkers and examines their usefulness in the ICU.

\section{Detection of cardiac dysfunction in the ICU}

Traditionally, the intensivist has relied on medical history, physical examination and basic investigations such as the electrocardiogram and the chest X-ray scan to detect cardiac dysfunction. Occasionally, invasive measurements such as the pulmonary artery catheter will be employed. Although echocardiography can play a major role, the limited availability

$\mathrm{BNP}=\mathrm{B}$-type natriuretic peptide; CK-MB = creatine kinase-myocardial band; CRP $=$ C-reactive protein; $\mathrm{cTn}=$ cardiac troponins; $\mathrm{cTnl}=\mathrm{cardiac}$ troponin I; cTnT = cardiac troponin $\mathrm{T} ; \mathrm{HF}=$ heart failure; $\mathrm{H}-\mathrm{FABP}=$ heart-type fatty acid binding protein; ICU = intensive care unit; IL = interleukin; $\mathrm{SRMD}=$ sepsis-related myocardial dysfunction; $\mathrm{TNF}=$ tumor necrosis factor. 
in many ICUs prompts the need for a simpler method to detect cardiac dysfunction. Serum biomarkers seem able to fulfill this role, and some have been evaluated for uses in myocardial ischemia and necrosis, acute decompensating $\mathrm{HF}$, reversible myocardial depression, valvular disease and pulmonary embolus.

\section{Acute heart failure}

Nearly 5 million people in the United States and at least 10 million people in Europe have HF. In the United States, HF accounted for at least $20 \%$ of all hospital admissions for patients over 65 years old [4]. From 1989 to 2003, approximately 14,000 patients were diagnosed with HF in New South Wales, Australia each year [5].

\section{B-type natriuretic peptide}

B-type natriuretic peptide (BNP) is a 32-amino-acid peptide secreted mainly by the cardiac ventricles in response to pressure or volume overloading (ventricular stretch) [6]. BNP causes diuresis and natriuresis by decreasing tubular salt and water reuptake, increasing the glomerular filtration rate and inhibiting angiotensin action on the proximal tubule [7]. BNP also induces vasodilatation, thereby reducing afterload [8]. The peptide therefore plays an important role in the maintenance of circulatory homeostasis and serves to protect the cardiovascular system from volume overload. BNP has been used to differentiate cardiac causes of dyspnea from pulmonary causes in the emergency setting [9].

A number of clinical and epidemiology studies have demonstrated the relationship between $\mathrm{HF}$ and BNP or N-terminalproBNP [10-12]. BNP is now commonly used to assist the diagnosis of $\mathrm{HF}$, and has been endorsed as a useful diagnostic marker for HF $[13,14]$. In the Breathing Not Properly study, a plasma BNP level $>100 \mathrm{pg} / \mathrm{ml}$ was demonstrated to predict congestive HF (sensitivity $=90 \%$, specificity $=73 \%$ ) [15]. BNP fails to correlate with the New York Heart Association class of dyspnea, however, and does not predict the severity of HF [16]. BNP is elevated in a number of conditions and is not specific to heart failure (Table 1). Considering the consistent high negative predictive values, BNP is most useful as a rule-out tool clinically.

In the ICU, plasma BNP concentrations are increased in patients with different types of cardiac dysfunction, including heart failure, left ventricular diastolic dysfunction, right ventricular pressure overload, and valvular stenosis. A BNP level $>144 \mathrm{pg} / \mathrm{ml}$ predicts cardiac dysfunction with high sensitivity (92\%) and high specificity (86\%) [2]. As BNP is increased in a variety of cardiac conditions, it offers little help in differential diagnosis and has low specificity for detecting specific cardiac disease such as heart failure [2]. BNP levels are also found to be significantly confounded by age, gender and fluid loading $[1,17,18]$. Owing to its high negative predictive value, BNP is best used for ruling out cardiac dysfunction. Since BNP is increased in various cardiac
Table 1

Conditions or factors commonly associated with B-type natriuretic peptide or $\mathbf{N}$-terminal-pro-B-type natriuretic peptide elevations

Age

Arrhythmias

Cardiomyopathy: hypertrophic, ischemic, or dilated

Congestive heart failure

Coronary artery disease

Gender

Hypertension

Left ventricular diastolic dysfunction

Pulmonary embolism

Renal failure

Right heart failure

Right ventricular overloading: fluid, or pressure overloading

Sepsis or septic shock

Sepsis-related myocardial dysfunction

conditions, the use of BNP as a specific diagnostic tool for HF cannot be recommended in the ICU.

\section{Troponins}

Although cardiac troponins (cTn) were initially used as serum markers for myocardial infarction, it is now known that cTn were also elevated in patients with HF even in the absence of overt ischemia $[19,20]$. The percentage of HF patients with elevated cTn could be as high as 45\% [21]. The mechanism for this elevation is believed to be due to ongoing myocyte injury and the progressive loss of cardiac myocytes, hence releasing cTn into the circulation $[22,23]$.

As a diagnostic tool for HF, however, cTn lack both sensitivity and specificity. cTn are more useful as a prognostic tool. Increased serum cTn, either cardiac troponin I (cTnl) or cardiac troponin $\mathrm{T}(\mathrm{cTnT})$, in patients with $\mathrm{HF}$ have been demonstrated to be associated with increased risks of cardiac events, rehospitalization and mortality $[19,21,24,25]$.

\section{Other potential heart failure markers}

$\mathrm{IL}-18$ is a member of the IL-1 family and possesses proinflammatory functions. IL-18 induces TNF $\alpha$ and IL-6. Circulating $\mathrm{LL}-18$ is markedly increased in patient with congestive $H F$, and is decreased with inotropic treatment [26,27]. As plasma IL-18 levels decrease with improving clinical status, IL-18 can be used as a surrogate for guided therapy [27]. Noteworthy, however, is the fact that IL-18 is also elevated in ischemic heart disease [28].

Carbohydrate antigen 125 was originally used as a tumor marker but was later also found to be increased in patients 
with HF $[29,30]$. Serum carbohydrate antigen 125 correlates with clinical status (New York Heart Association class), and correlates weakly with right atrial pressure, right ventricular systolic pressure and pulmonary artery wedge pressure [31,32]. Interestingly, carbohydrate antigen 125 does not seem to correlate with most of the echocardiographic left ventricular systolic and diastolic function parameters [31,32]. The fact that carbohydrate antigen 125 is also increased in isolated right heart failure, pericardial effusion and renal dysfunction precludes its use as a diagnostic tool for HF [33,34], although its significant reduction with aggressive treatment may render it a surrogate marker [31].

\section{Cardiac injury and necrosis Creatine kinase-myocardial band}

Irreversible myocardial necrosis is the landmark of acute myocardial infarction. Myocardial injury leads to the release of specific cytosolic substances that can be used as a marker for injury. Creatine kinase-myocardial band (CK-MB) is an enzyme present primarily in cardiac muscles [35]. The enzyme is released rapidly (within 4 to 6 hours) into the circulation after the onset of infarction. It peaks at 24 hours, and returns to normal levels by 36 to 72 hours [36]. CK-MB is not cardiospecific, however, and skeletal muscle injury can increase its circulatory level [37]. Other uses of CK-MB include estimating the infarct time, the infarct size and expansion, and reinfarction [38].

\section{Troponins}

Troponin $\mathrm{T}$ and troponin I are part of the contractile apparatus of striated muscle, including the cardiac myocytes. cTnT and cTnl are the most specific and sensitive markers of myocardial injury, and there is no clinical difference between cTnT and cTnl for diagnosing cardiac necrosis [39]. The trigger for cTn release is necrosis, and cTn assays can detect as little as $1 \mathrm{~g}$ myocardial necrosis [40]. cTn begin to increase within 2 to 4 hours after onset of symptoms, and remain elevated for days. Early release is believed to be attributable to the cytosolic pool, and later release attributable to the structural pool. cTn are particularly useful in determining whether a given event is acute, chronic or reinfarction by observing if the level is increasing or re-elevating.

Not only are cTn elevated in patients with acute and chronic cardiovascular disease, but also in patients with noncardiovascular disease. Studies in both symptomatic and asymptomatic patients have shown that renal failure is associated with chronic elevations of cTn [41]. Sepsis or pulmonary embolism can also independently increase cTn [42]. Other causes of cTn elevation include trauma, pericarditis, HF, hypertension, and inflammatory diseases (Table 2) [43]. Encountering patients with elevated cTn without apparent causes is also not infrequent. There are a number of reasons for this, including the high sensitivities of the new-generation assays, the use of low cutoff points and the imprecision of the assays. In view of this uncertainty,
Table 2

\section{Conditions commonly associated with cardiac troponin} elevations

\author{
Arrhythmias \\ Congestive heart failure \\ Coronary artery disease \\ Coronary vasospasm \\ Critically ill patient \\ Hypertension \\ Myocarditis \\ Pericarditis, acute \\ Pulmonary embolism \\ Pulmonary hypertension, severe \\ Renal failure \\ Sepsis/septic shock \\ Sepsis-related myocardial dysfunction \\ Systemic inflammatory diseases \\ Takotsubo cardiomyopathy
}

Trauma

serial testing has been recommended to improve specificity [44]. A single measurement of cTn, albeit elevated, does not reflect the mechanism of myocardial damage and should not be used alone to diagnose myocardial infarction. cTn, however, is still useful in predicting outcomes in patients with or without acute coronary syndromes $[45,46]$.

\section{Heart-type fatty acid binding protein}

Heart-type fatty acid binding protein ( $\mathrm{H}-\mathrm{FABP})$ is a small cytosolic protein found in cardiomyocytes responsible for fatty acid transportation [47]. H-FABP is rapidly released into the circulation following myocardial injury, and is detectable within 2 to 3 hours of the onset of clinical symptoms [48]. The diagnostic sensitivity of H-FABP for acute myocardial infarction in the superacute phase (within the first 3 hours) is 93.1\%, which is higher than that for CK-MB and for cTn. The specificity, however, is lower than that of cTn (64.3\%) [49].

In a study involving 108 patients with acute ischemic-type chest pain admitted to a mobile intensive care unit, H-FABP showed a better sensitivity to identify myocardial infarction than cTnl, myoglobin and CK-MB. In patients with normal prehospital cTnl levels and no ST-elevation $(n=63)$, a positive H-FABP test had $83.3 \%$ sensitivity and $93.3 \%$ specificity for predicting evolving myocardial infarction [50]. $\mathrm{H}$-FABP also offers better sensitivity than cTnT for detecting ongoing myocardial damage in congestive HF [51]. Elevated serum $\mathrm{H}-\mathrm{FABP}$ is associated with an increased risk of death and major cardiac events in patients with acute coronary syndromes despite negative serum cTn and BNP [52]. 


\section{Inflammatory markers of atherosclerotic plaque}

Inflammation plays a key role in coronary artery disease [53]. All stages of plaque development and eventual rupture leading to acute coronary syndromes can be considered an inflammatory response [54]. The detection of key molecules involved in the atherosclerotic inflammatory cascade therefore offers an attractive approach for detecting cardiac ischemia and predicting outcomes [55].

\section{C-reactive protein}

C-reactive protein (CRP) is produced mainly in the liver and is believed to have a direct role in the pathophysiology of atherosclerosis. CRP enhances macrophage uptake of lowdensity lipoprotein and contributes to foam cell formation. The protein also causes plaque instability, induces adhesion molecule expression, and associates with endothelial dysfunction [56,57]. CRP was elevated in patients with unstable angina but not in those with variant angina caused by vasospasm, indicating that CRP is associated with inflammation in the coronary artery rather than in the ischemic myocardium [58]. CRP was also increased in other inflammatory conditions such as acute injury, infection, and chronic renal failure $[59,60]$. High levels of CRP in unstable angina are associated with worsening outcome [61].

\section{Interleukins}

IL-6, a proinflammatory cytokine produced by macrophages in atherosclerotic plaque, induces hepatic synthesis of all the acute phase proteins, including CRP $[54,62]$. Elevated IL-6 was associated with a 3.5 -fold increase in 1-year mortality in patients with acute coronary syndrome [63]. Healthy individuals with high IL-6 also had an increased risk for future myocardial infarction [64]. One should bear in mind, however, that IL-6 is unlikely to be helpful in differentiating diseases because it is an inflammatory cytokine that is elevated in many diseases, and in almost any inflammatory disease. As such, IL-6 is not specific enough to be used as a diagnostic tool.

IL-18 is also a proinflammatory cytokine that is highly expressed in atherosclerotic plaque (macrophages). Significantly higher levels of IL-18 mRNA were found in symptomatic (unstable) plaque than in asymptomatic (stable) plaque, suggesting IL-18 destabilizes atherosclerotic plaque leading to ischemic syndromes $[65,66]$. IL-18 was a strong predictor of death from cardiovascular causes in patients with coronary artery disease [67]. Owing to its high level in HF, IL-18 is not suitable for selectively diagnosing ischemic heart disease.

\section{Sepsis-related myocardial dysfunction}

Sepsis-related myocardial dysfunction (SRMD) refers to the transient depression in left ventricular function in patients with sepsis [68]. SRMD is a common complication, occurring in up to $50 \%$ of septic patients, and early recognition and aggressive supportive therapy are mandatory as the mortality in these patients is high [69].

\section{B-type natriuretic peptide}

Patients with severe sepsis or septic shock had elevated BNP levels $[1,2,70]$. BNP correlated with the cardiac index in patients with septic shock, and levels were higher in those with reduced left ventricular function [71,72]. Our recent study found that patients with severe sepsis or septic shock had higher BNP than normal levels regardless of cardiac function. Interestingly, differentiation of septic patients with or without SRMD with BNP alone was proved not practical as both populations demonstrated similar levels of BNP [73]. Given the number of confounding factors of BNP in this setting, the specific use of BNP in diagnosing SRMD is not recommended at this stage $[2,74]$.

\section{Cardiac troponins}

cTn levels have been shown to be associated with SRMD $[75,76]$. Neither myocardial ischemia nor necrosis (irreversible damage) could fully explain the elevated cTn levels observed in SRMD [77]. It is postulated that a transient (reversible) increase in membrane permeability of the cardiomyocytes in SRMD, together with intracellular degradation of troponin I, was responsible for the increased cTn levels $[78,79]$. The use of cTn as a diagnostic tool for SRMD is again limited by its low specificity.

\section{Pulmonary embolism}

cTn and BNP were elevated in patients with pulmonary embolism, and could be the result of right ventricular overload or dysfunction secondary to pulmonary hypertension $[80,81]$. About $70 \%$ of patients with pulmonary embolism had elevated cTnl, and was significantly associated with right ventricular dysfunction [80]. BNP and N-terminal-proBNP were also found to be elevated in pulmonary embolism, but only in patients with concomitant right ventricular dysfunction [82]. BNP concentrations were found proportional to the severity of embolism, probably due to the increasing degree of right ventricular stress [83].

In a recent single-centered small study, it was observed that patients with elevated $\mathrm{H}-\mathrm{FABP}$ on admission had a higher risk of developing major pulmonary embolism-related complications [84]. H-FABP was also found to have a better discriminatory ability for pulmonary embolism-related complications than cTnT and N-terminal-proBNP [84].

\section{Other potential cardiac biomarkers Ischemia-modified albumin}

The ability of human serum albumin to bind cobalt is reduced in myocardial ischemia $[85,86]$. Using blood samples collected within 2 hours of arrival at the Emergency Department, ischemia-modified albumin (noncobalt-binding albumin) was found to be increased in patients with unstable angina (sensitivity $=91 \%$ ) [87]. The sensitivities, however, were lower for detecting myocardial infarction. Muscle ischemia, low albumin levels and physical exercise have all been shown to affect ischemia-modified albumin levels [88-90]. 


\section{Whole blood choline}

Choline is released by cleavage of membrane phospholipids by phospholipase D. Whole blood choline and plasma choline concentrations increase rapidly after activation of phospholipase D in acute coronary syndromes [91]. Whole blood choline and plasma choline are significant and independent predictors of major cardiac events in admission cTnT-negative patients [92]. Both cholines are predictive for events related to tissue ischemia, and are independent of other known factors such as age, gender, prior myocardial infarction, coronary risk factors and the electrocardiogram [92].

\section{CD154}

The soluble CD40 ligand, now known as CD154, is found both on the cell surface and in soluble form. CD154 is a platelet-derived inflammatory cytokine and can be found on lymphocytes and the endothelial surface. Interaction with the CD40 receptor leads to $B$-cell activation and induction of other inflammatory markers, such as cell adhesion molecules, cytokines and chemokines [93]. In patients with HF, the abundance of CD154 on platelets is increased and correlates with New York Heart Association classification [94]. Elevated CD154 levels independently predict cardiovascular events and death [95].

\section{Urocortin}

Urocortin, like BNP, is a cardioprotective peptide and can be found in the brain and in the heart [96]. Urocortin increases myocardial contractility, induces vasodilatation, and possesses antiapoptotic and anti-inflammatory activities [97,98]. In patients with HF, urocortin is associated with left ventricular dysfunction [99]. Studies involving humans are limited, and more research is needed before urocortin can be used as a biomarker.

\section{Myeloperoxidase}

Myeloperoxidase, a proinflammatory enzyme involved in lowdensity lipoprotein oxidation, is significantly elevated in HF patients [100]. Elevated plasma myeloperoxidase levels in HF subjects were associated with worsening conditions [101]. In the emergency setting, myeloperoxidase predicts the risk of myocardial infarction in patients with chest pain even in the absence of cardiac necrosis [102].

\section{Multimarker approach}

The reliance on a single biomarker for diagnostic or prognostic purpose has in many cases proven unsatisfactory. A number of studies have demonstrated that the value of using biomarkers for diagnosis or prognosis could be more apparent if several biomarkers were used together. For example, when CRP was used in conjunction with BNP or cTn in the emergency and cardiology settings, the prognostic value was better than each biomarker used singly [103,104]. Similarly, the combination of cTnT, electrocardiogram and ischemiamodified albumin could identify $95 \%$ of patients whose chest pain was attributable to ischemic heart disease $[87,105]$.

\section{Intensive care unit}

A number of cardiac biomarkers are now commonly used in the ICU; in particular, cTn, CRP, and CK-MB. cTn are known to be increased in intensive care patients, and are not confined to patients with cardiac injury or acute coronary syndromes [106-109]. Nonthrombotic cardiac conditions, as well as noncardiac conditions, are also associated with increased cTn levels (Table 2). The presence of elevated cTn per se is not sufficient to diagnose cardiac injury [110,111]. Based on the data provided by Lim and colleagues [111], the Bayesian probability that a critically ill patient with an increased troponin level will have cardiac injury (myocardial infarction) is between 0.5 and 0.6 ; that is, the chance of prediction is only slightly better than tossing a coin.

Although CRP has been used as a cardiac marker in the emergency or cardiology settings, it is not normally used as a cardiac biomarker in the ICU. CRP is instead used as an acute phase inflammatory marker to assist the diagnosis of infection [112,113]. In a heterogeneous ICU population, elevated concentrations of serum CRP on ICU admission were correlated with an increased risk of organ failure and death [114]. To date, we are not aware of any study demonstrating the usefulness of CRP as a cardiac biomarker in the intensive care setting.

BNP is also a promising biomarker for use in the ICU, but its application is confined mainly to screening purposes. Applications in the area of differential diagnosis, guiding treatment as well as prognosis are still developing.

Given the comorbidities, aggressive treatments and the lack of specificity and sensitivity of a single cardiac marker, it is probable that the intensive care setting will benefit from the multimarker approach. The development of a multimarker approach for ICU use, however, should be distinctive; the question of which biomarkers are the best to use will require further research.

\section{Conclusion}

There is no doubt that cardiac biomarkers play an important role in providing additional information for differential diagnosis in the ICU. This additional information, depending on the biomarker(s) used, may include the presence or absence of cardiac disease, cardiac injury, atherosclerotic plaque, or pulmonary embolism (Fig. 1). While most information could be obtained from detailed clinical investigations, such as echocardiography, angiography and other hemodynamic assessments, the biomarker approach provides quick information and adds value to the diagnostic process. The helpfulness of the biomarker information will depend on the way in which it is used (for example, sampling time, the cutoff points chosen), the clinician's belief and approach, as well as the clinical context. The main attractions of using biomarkers are the close link between the 


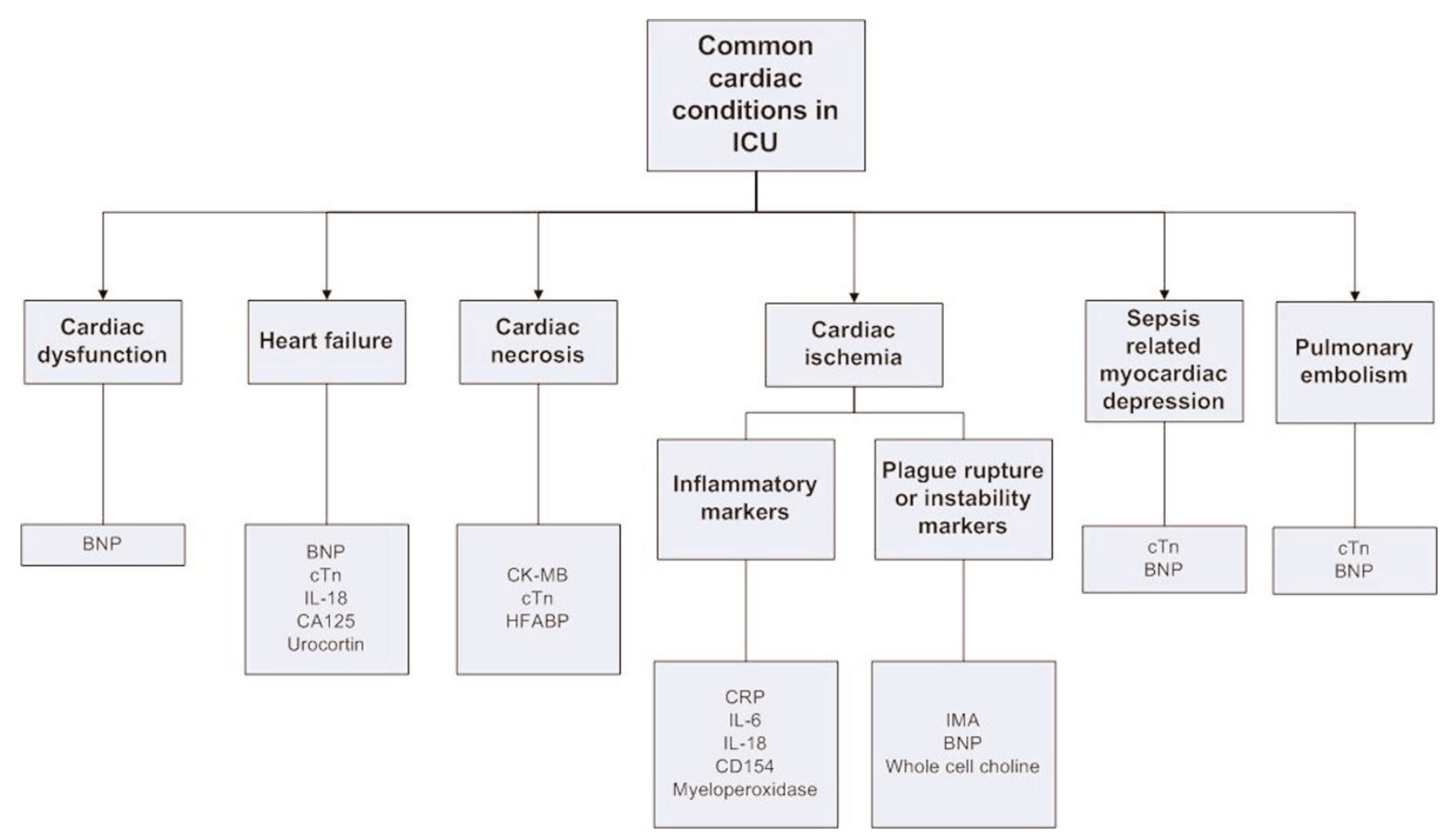

Common cardiac conditions encountered in the intensive care unit and the related biomarkers. Note the lack of specificity of some biomarkers. BNP, B-type natriuretic peptide; CA125, carbohydrate antigen 125; CD154, soluble CD40 ligand; CK-MB, creatine kinase-myocardial band; CRP, C-reactive protein; cTn, cardiac troponins; ICU, intensive care unit; IL, interleukin; IMA, ischemia-modified albumin; HFABP, heart-type fatty acid binding protein.

pathophysiology and the biomarkers, the rapid appearance of the biomarkers, the correlation between the biomarkers and the severity of the disease, the provision of prognosis, and the ease of performing the test.

The use of cardiac biomarkers in the ICU continues to evolve with new findings. Ideally, the biomarkers should be specific for cardiac diseases, but this is both theoretically and practically impossible due to the sharing of common biochemical or immunological pathways of the pathophysiological processes. Despite most of the biomarkers lacking sensitivity and specificity, this should not prevent biomarkers being used in a clinically useful way. Clinicians need to be aware of the biomarkers' limitations, and should interpret them within the clinical context. A multimarker approach may prove a valuable approach in the future for the ICU.

\section{Competing interests}

The authors declare that they have no competing interests.

\section{References}

1. McLean AS, Huang SJ, Nalos M, Tang B, Stewart DE: The confounding effects of age, gender, serum creatinine, and electrolyte concentrations on plasma B-type natriuretic peptide concentrations in critically ill patients. Crit Care Med 2003, 31: 2611-2618.

2. McLean AS, Tang B, Nalos M, Huang SJ, Stewart DE: Increased B-type natriuretic peptide (BNP) level is a strong predictor for cardiac dysfunction in intensive care unit patients. Anaesth Intensive Care 2003, 31:21-27.

3. McLean AS, Huang SJ: Intensive care echocardiography. In 2006 Yearbook of Intensive Care and Emergency Medicine. Edited by Vincent J-L. Berlin: Springer-Verlag; 2006:131-141.

4. Jessup M, Brozena S: Heart failure. N Engl J Med 2003, 348: 2007-2018.

5. McLean AS, Eslick GD, Coats AJ: The epidemiology of heart failure in Australia. Int J Cardiol 2007, 118:370-374.

6. Vanderheyden M, Goethals M, Verstreken S, De Bruyne B, Muller $\mathrm{K}$, Van Schuerbeeck E, Bartunek J: Wall stress modulates brain natriuretic peptide production in pressure overload cardiomyopathy. J Am Coll Cardiol 2004, 44:2349-2354.

7. Houben AJ, van der Zander K, de Leeuw PW: Vascular and renal actions of brain natriuretic peptide in man: physiology and pharmacology. Fundam Clin Pharmacol 2005, 19:411-419.

8. van der Zander K, Houben AJ, Kroon AA, de Leeuw PW: Effects of brain natriuretic peptide on forearm vasculature: comparison with atrial natriuretic peptide. Cardiovasc Res 1999, 44: 595-600.

9. Maisel AS, McCord J, Nowak RM, Hollander JE, Wu AH, Duc P, Omland T, Storrow AB, Krishnaswamy P, Abraham WT, Clopton P, Steg G, Aumont MC, Westheim A, Knudsen CW, Perez A, Kamin R, Kazanegra R, Herrmann HC, McCullough PA: Bedside B-type natriuretic peptide in the emergency diagnosis of heart failure with reduced or preserved ejection fraction. Results from the Breathing Not Properly Multinational Study. J Am Coll Cardio/ 2003, 41:2010-2017. 
10. Davis M, Espiner E, Richards G, Billings J, Town I, Neill A, Drennan C, Richards M, Turner J, Yandle T: Plasma brain natriuretic peptide in assessment of acute dyspnoea. Lancet 1994, 343:440-444.

11. McDonagh TA, Robb SD, Murdoch DR, Morton JJ, Ford I, Morrison CE, Tunstall-Pedoe H, McMurray JJ, Dargie HJ: Biochemical detection of left-ventricular systolic dysfunction. Lancet 1998, 351:9-13.

12. Januzzi JL, Jr, Camargo $C A$, Anwaruddin $S$, Baggish $A L$, Chen $A A$, Krauser DG, Tung R, Cameron R, Nagurney JT, Chae CU, LloydJones DM, Brown DF, Foran-Melanson S, Sluss PM, LeeLewandrowski E, Lewandrowski KB: The N-terminal Pro-BNP investigation of dyspnea in the emergency department (PRIDE) study. Am J Cardio/ 2005, 95:948-954.

13. Cowie MR, Struthers AD, Wood DA, Coats AJ, Thompson SG, Poole-Wilson PA, Sutton GC: Value of natriuretic peptides in assessment of patients with possible new heart failure in primary care. Lancet 1997, 350:1349-1353.

14. Remme WJ, Swedberg K: Guidelines for the diagnosis and treatment of chronic heart failure. Eur Heart J 2001, 22:15271560.

15. McCullough PA, Nowak RM, McCord J, Hollander JE, Herrmann HC, Steg PG, Duc P, Westheim A, Omland T, Knudsen CW, Storrow AB, Abraham WT, Lamba S, Wu AH, Perez A, Clopton P, Krishnaswamy $\mathrm{P}$, Kazanegra R, Maisel AS: B-type natriuretic peptide and clinical judgment in emergency diagnosis of heart failure: analysis from Breathing Not Properly (BNP) Multinational Study. Circulation 2002, 106:416-422.

16. Maisel A, Hollander JE, Guss D, McCullough P, Nowak R, Green G, Saltzberg M, Ellison SR, Bhalla MA, Bhalla V, Clopton P, Jesse R: Primary results of the Rapid Emergency Department Heart Failure Outpatient Trial (REDHOT). A multicenter study of Btype natriuretic peptide levels, emergency department decision making, and outcomes in patients presenting with shortness of breath. J Am Coll Cardiol 2004, 44:1328-1333.

17. McLean AS, Huang SJ: The applications of B-type natriuretic peptide measurement in the intensive care unit. Curr Opin Crit Care 2005, 11:406-412.

18. McLean AS, Poh G, Huang SJ: The effects of acute fluid loading on plasma B-type natriuretic peptide levels in a septic shock patient. Anaesth Intensive Care 2005, 33:528-530.

19. Nellessen U, Goder S, Schobre R, Abawi M, Hecker H, Tschoke $\mathrm{S}$ : Serial analysis of troponin I levels in patients with ischemic and nonischemic dilated cardiomyopathy. Clin Cardiol 2006, 29:219-224.

20. Wallace TW, Abdullah SM, Drazner MH, Das SR, Khera A, McGuire DK, Wians F, Sabatine MS, Morrow DA, de Lemos JA: Prevalence and determinants of troponin T elevation in the general population. Circulation 2006, 113:1958-1965.

21. Liu Z, Cui L, Wang Y, Guo Y: Cardiac troponin I and ventricular arrhythmia in patients with chronic heart failure. Eur J Clin Invest 2006, 36:466-472.

22. Matsumori A, Kawai C, Yamada T, Ohkusa T, Morishima S, Tamaki N, Watanabe Y, Yonekura Y, Endo K, Konishi J, Yoshida A: Mechanism and significance of myocardial uptake of antimyosin antibody in myocarditis and cardiomyopathy: clinical and experimental studies. Clin Immunol Immunopathol 1993, 68: 215-219.

23. Sato $Y$, Kita $T$, Takatsu $Y$, Kimura $T$ : Biochemical markers of myocyte injury in heart failure. Heart 2004, 90:1110-1113.

24. Latini R, Masson S, Anand IS, Missov E, Carlson M, Vago T, Angelici L, Barlera S, Parrinello G, Maggioni AP, Tognoni G, Cohn $J N$ : Prognostic value of very low plasma concentrations of troponin $\mathrm{T}$ in patients with stable chronic heart failure. Circulation 2007, 116:1242-1249.

25. Nishio $Y$, Sato $Y$, Taniguchi $R$, Shizuta $S$, Doi $T$, Morimoto $T$, Kimura T, Kita $\mathrm{T}$ : Cardiac troponin $\mathrm{T}$ vs other biochemical markers in patients with congestive heart failure. Circ J 2007, 71:631-635

26. Mallat Z, Heymes C, Corbaz A, Logeart D, Alouani S, Cohen-Solal A, Seidler T, Hasenfuss G, Chvatchko Y, Shah AM, Tedgui A: Evidence for altered interleukin 18 (IL)-18 pathway in human heart failure. FASEB J 2004, 18:1752-1754

27. White $M$, Ducharme A, Ibrahim R, Whittom L, Lavoie J, Guertin MC, Racine N, He Y, Yao G, Rouleau JL, Schiffrin EL, Touyz RM: Increased systemic inflammation and oxidative stress in patients with worsening congestive heart failure: improve- ment after short-term inotropic support. Clin Sci (Lond) 2006, 110:483-489.

28. Pomerantz BJ, Reznikov LL, Harken AH, Dinarello CA: Inhibition of caspase 1 reduces human myocardial ischemic dysfunction via inhibition of IL-18 and IL-1 $\beta$. Proc Natl Acad Sci USA 2001, 98:2871-2876.

29. Bast RC, Jr, Klug TL, St John E, Jenison E, Niloff JM, Lazarus $H$, Berkowitz RS, Leavitt T, Griffiths CT, Parker L, Zurawski VR Jr, Knapp RC: A radioimmunoassay using a monoclonal antibody to monitor the course of epithelial ovarian cancer. $N$ Engl J Med 1983, 309:883-887.

30. Nagele H, Bahlo M, Klapdor R, Schaeperkoetter D, Rodiger W: CA 125 and its relation to cardiac function. Am Heart J 1999, 137:1044-1049.

31. D'Aloia A, Faggiano P, Aurigemma G, Bontempi L, Ruggeri G, Metra M, Nodari S, Dei Cas L: Serum levels of carbohydrate antigen 125 in patients with chronic heart failure: relation to clinical severity, hemodynamic and Doppler echocardiographic abnormalities, and short-term prognosis. J Am Coll Cardiol 2003, 41:1805-1811.

32. Kouris NT, Zacharos ID, Kontogianni DD, Goranitou GS, Sifaki MD, Grassos HE, Kalkandi EM, Babalis DK: The significance of CA125 levels in patients with chronic congestive heart failure. Correlation with clinical and echocardiographic parameters. Eur J Heart Fail 2005, 7:199-203.

33. Mathew B, Bhatia V, Mahy IR, Ahmed I, Francis L: Elevation of the tumor marker CA125 in right heart failure. South Med $J$ 2004, 97:1013-1014.

34. Seo T, Ikeda Y, Onaka H, Hayashi T, Kawaguchi K, Kotake C, Toda $\mathrm{T}$, Kobayashi K: Usefulness of serum CA125 measurement for monitoring pericardial effusion. Jpn Circ J 1993, 57:489-494.

35. van der Veen KJ, Willebrands AF: Isoenzymes of creatine phosphokinase in tissue extracts and in normal and pathological sera. Clin Chim Acta 1966, 13:312-316.

36. Sobel BE, Shell WE: Serum enzyme determinations in the diagnosis and assessment of myocardial infarction. Circulation 1972, 45:471-482

37. Collinson PO, Chandler HA, Stubbs PJ, Moseley DS, Lewis D, Simmons MD: Measurement of serum troponin T, creatine kinase MB isoenzyme, and total creatine kinase following arduous physical training. Ann Clin Biochem 1995, 32:450453.

38. Panteghini M: Acute coronary syndrome: biochemical strategies in the troponin era. Chest 2002, 122:1428-1435.

39. Jaffe AS, Ravkilde J, Roberts R, Naslund U, Apple FS, Galvani M, Katus $\mathrm{H}$ : It's time for a change to a troponin standard. Circulation 2000, 102:1216-1220.

40. Alpert JS, Thygesen K, Antman E, Bassand JP: Myocardial infarction redefined - a consensus document of The Joint European Society of Cardiology/American College of Cardiology Committee for the redefinition of myocardial infarction. $J \mathrm{Am}$ Coll Cardiol 2000, 36:959-969.

41. De Zoysa JR: Cardiac troponins and renal disease. Nephrology 2004, 9:83-88.

42. Wu AH, Jaffe AS: The clinical need for high-sensitivity cardiac troponin assays for acute coronary syndromes and the role for serial testing. Am Heart $J$ 2008, 155:208-214.

43. Donnino MW, Karriem-Norwood V, Rivers EP, Gupta A, Nguyen HB, Jacobsen G, McCord J, Tomlanovich MC: Prevalence of elevated troponin $I$ in end-stage renal disease patients receiving hemodialysis. Acad Emerg Med 2004, 11:979-981.

44. Jaffe AS, Babuin L, Apple FS: Biomarkers in acute cardiac disease: the present and the future. J Am Coll Cardiol 2006, 48:1-11.

45. Hamm CW, Giannitsis E, Katus HA: Cardiac troponin elevations in patients without acute coronary syndrome. Circulation 2002, 106:2871-2872.

46. Aviles RJ, Askari AT, Lindahl B, Wallentin L, Jia G, Ohman EM, Mahaffey KW, Newby LK, Califf RM, Simoons ML, Topol EJ, Berger P, Lauer MS: Troponin T levels in patients with acute coronary syndromes, with or without renal dysfunction. $N$ Engl J Med 2002, 346:2047-2052.

47. Glatz JF, Paulussen RJ, Veerkamp JH: Fatty acid binding proteins from heart. Chem Phys Lipids 1985, 38:115-129.

48. Tanaka T, Hirota Y, Sohmiya K, Nishimura S, Kawamura K: Serum and urinary human heart fatty acid-binding protein in acute myocardial infarction. Clin Biochem 1991, 24:195-201. 
49. Tanaka T, Sohmiya K, Kitaura Y, Takeshita H, Morita H, Ohkaru Y, Asayama K, Kimura $\mathrm{H}$ : Clinical evaluation of point-of-caretesting of heart-type fatty acid-binding protein (H-FABP) for the diagnosis of acute myocardial infarction. J Immunoassay Immunochem 2006, 27:225-238.

50. Ecollan P, Collet JP, Boon G, Tanguy ML, Fievet ML, Haas R, Bertho N, Siami S, Hubert JC, Coriat P, Montalescot G: Pre-hospital detection of acute myocardial infarction with ultra-rapid human fatty acid-binding protein (H-FABP) immunoassay. Int J Cardiol 2007, 119:349-354.

51. Niizeki T, Takeishi $Y$, Arimoto $T$, Takabatake N, Nozaki N, Hirono O, Watanabe T, Nitobe J, Harada M, Suzuki S, Koyama Y, Kitahara T, Sasaki T, Kubota I: Heart-type fatty acid-binding protein is more sensitive than troponin $\mathrm{T}$ to detect the ongoing myocardial damage in chronic heart failure patients. $J$ Card Fail 2007, 13:120-127.

52. O'Donoghue M, de Lemos JA, Morrow DA, Murphy SA, Buros JL, Cannon CP, Sabatine MS: Prognostic utility of heart-type fatty acid binding protein in patients with acute coronary syndromes. Circulation 2006, 114:550-557.

53. Libby P: Inflammation in atherosclerosis. Nature 2002, 420: 868-874.

54. Hansson GK: Inflammation, atherosclerosis, and coronary artery disease. N Engl J Med 2005, 352:1685-1695

55. Larsson PT, Hallerstam S, Rosfors S, Wallen NH: Circulating markers of inflammation are related to carotid artery atherosclerosis. Int Angio/ 2005, 24:43-51.

56. Pasceri V, Cheng JS, Willerson JT, Yeh ET: Modulation of Creactive protein-mediated monocyte chemoattractant protein1 induction in human endothelial cells by anti-atherosclerosis drugs. Circulation 2001, 103:2531-2534.

57. Tanaka A, Shimada K, Sano T, Namba M, Sakamoto T, Nishida Y, Kawarabayashi T, Fukuda D, Yoshikawa J: Multiple plaque rupture and C-reactive protein in acute myocardial infarction. J Am Coll Cardiol 2005, 45:1594-1599.

58. Liuzzo G, Biasucci LM, Rebuzzi AG, Gallimore JR, Caligiuri G, Lanza GA, Quaranta G, Monaco C, Pepys MB, Maseri A: Plasma protein acute-phase response in unstable angina is not induced by ischemic injury. Circulation 1996, 94:2373-2380.

59. Wong CK, Szeto CC, Chan MH, Leung CB, Li PK, Lam CW: Elevation of pro-inflammatory cytokines, $\mathrm{C}$-reactive protein and cardiac troponin $\mathrm{T}$ in chronic renal failure patients on dialysis. Immunol Invest 2007, 36:47-57.

60. Deodhar SD: C-reactive protein: the best laboratory indicator available for monitoring disease activity. Cleveland Clin J Med 1989, 56:126-130.

61. Lindahl B, Toss $\mathrm{H}$, Siegbahn A, Venge $\mathrm{P}$, Wallentin L: Markers of myocardial damage and inflammation in relation to long-term mortality in unstable coronary artery disease. FRISC Study Group. Fragmin during Instability in Coronary Artery Disease. N Engl J Med 2000, 343:1139-1147.

62. Schieffer B, Schieffer E, Hilfiker-Kleiner D, Hilfiker A, Kovanen PT, Kaartinen M, Nussberger J, Harringer W, Drexler H: Expression of angiotensin II and interleukin 6 in human coronary atherosclerotic plaques: potential implications for inflammation and plaque instability. Circulation 2000, 101:1372-1378.

63. Lindmark E, Diderholm E, Wallentin L, Siegbahn A: Relationship between interleukin 6 and mortality in patients with unstable coronary artery disease: effects of an early invasive or noninvasive strategy. JAMA 2001, 286:2107-2113.

64. Ridker PM, Rifai N, Stampfer MJ, Hennekens CH: Plasma concentration of interleukin-6 and the risk of future myocardial infarction among apparently healthy men. Circulation 2000, 101:1767-1772.

65. Mallat Z, Corbaz A, Scoazec A, Besnard S, Leseche G, Chvatchko $Y$, Tedgui $A$ : Expression of interleukin-18 in human atherosclerotic plaques and relation to plaque instability. Circulation 2001, 104:1598-1603.

66. Zirlik A, Abdullah SM, Gerdes N, MacFarlane L, Schonbeck U, Khera A, McGuire DK, Vega GL, Grundy S, Libby P, de Lemos JA: Interleukin-18, the metabolic syndrome, and subclinical atherosclerosis: results from the Dallas Heart Study. Arterioscler Thromb Vasc Biol 2007, 27:2043-2049.

67. Blankenberg S, Tiret L, Bickel C, Peetz D, Cambien F, Meyer J, Rupprecht HJ: Interleukin-18 is a strong predictor of cardiovascular death in stable and unstable angina. Circulation 2002, 106:24-30.
68. Parker MM, Shelhamer JH, Bacharach SL, Green MV, Natanson C, Frederick TM, Damske BA, Parrillo JE: Profound but reversible myocardial depression in patients with septic shock. Ann Int Med 1984, 100:483-490.

69. Annane D, Bellissant E, Cavaillon JM: Septic shock. Lancet 2005, 365:63-78.

70. Cuthbertson BH, Patel RR, Croal BL, Barclay J, Hillis GS: B-type natriuretic peptide and the prediction of outcome in patients admitted to intensive care. Anaesthesia 2005, 60:16-21.

71. Witthaut R, Busch C, Fraunberger P, Walli A, Seidel D, Pilz G, Stuttmann R, Speichermann N, Verner L, Werdan K: Plasma atrial natriuretic peptide and brain natriuretic peptide are increased in septic shock: impact of interleukin-6 and sepsisassociated left ventricular dysfunction. Intensive Care Med 2003, 29:1696-1702.

72. Charpentier J, Luyt CE, Fulla $Y$, Vinsonneau C, Cariou A, Grabar S, Dhainaut JF, Mira JP, Chiche JD: Brain natriuretic peptide: a marker of myocardial dysfunction and prognosis during severe sepsis. Crit Care Med 2004, 32:660-665.

73. McLean AS, Huang SJ, Hyams S, Poh G, Nalos M, Pandit R, Balik $M$, Tang B, Seppelt I: Prognostic values of B-type natriuretic peptide in severe sepsis and septic shock. Crit Care Med 2007, 35:1019-1026.

74. McLean AS, Huang SJ: The applications of B-type natriuretic peptide measurement in the intensive care unit. Curr Opin Crit Care 2005, 11:406-412.

75. ver Elst KM, Spapen HD, Nguyen DN, Garbar C, Huyghens LP, Gorus FK: Cardiac troponins I and T are biological markers of left ventricular dysfunction in septic shock. Clin Chem 2000, 46:650-657.

76. Mehta NJ, Khan IA, Gupta V, Jani K, Gowda RM, Smith PR: Cardiac troponin I predicts myocardial dysfunction and adverse outcome in septic shock. Int J Cardio/ 2004, 95:13-17.

77. Cunnion RE, Schaer GL, Parker MM, Natanson C, Parrillo JE: The coronary circulation in human septic shock. Circulation 1986, 73:637-644.

78. Ammann P, Fehr T, Minder El, Gunter C, Bertel O: Elevation of troponin $I$ in sepsis and septic shock. Intensive Care Med 2001, 27:965-969.

79. Wu AH, Feng YJ, Moore R, Apple FS, McPherson PH, Buechler KF, Bodor G: Characterization of cardiac troponin subunit release into serum after acute myocardial infarction and comparison of assays for troponin T and I. American Association for Clinical Chemistry Subcommittee on cTnl Standardization. Clin Chem 1998, 44:1198-1208.

80. Amorim S, Dias P, Rodrigues RA, Araujo V, Macedo F, Maciel MJ, Goncalves FR: Troponin I as a marker of right ventricular dysfunction and severity of pulmonary embolism. Rev Port Cardiol 2006, 25:181-186.

81. Pruszczyk $\mathrm{P}: \mathrm{N}$-terminal pro-brain natriuretic peptide as an indicator of right ventricular dysfunction. J Card Fail 2005, 11: S65-S69.

82. Pruszczyk P, Kostrubiec M, Bochowicz A, Styczynski G, Szulc M, Kurzyna M, Fijalkowska A, Kuch-Wocial A, Chlewicka I, Torbicki A: $\mathrm{N}$-terminal pro-brain natriuretic peptide in patients with acute pulmonary embolism. Eur Respir J 2003, 22:649-653.

83. Kruger S, Graf J, Merx MW, Koch KC, Kunz D, Hanrath P, Janssens $\mathrm{U}$ : Brain natriuretic peptide predicts right heart failure in patients with acute pulmonary embolism. Am Heart $J$ 2004, 147:60-65.

84. Renaud $B$, Ngako A: Heart-type fatty acid-binding proteins $(H-$ FABP): a reliable tool for initial risk stratification of pulmonary embolism? Eur Heart J 2007, 28:146-147.

85. Bar-Or D, Lau E, Rao N, Bampos N, Winkler JV, Curtis CG: Reduction in the cobalt binding capacity of human albumin with myocardial ischemia [abstract]. Ann Emerg Med 1999; 34:S56.

86. Bar-Or D, Lau E, Winkler JV: A novel assay for cobalt-albumin binding and its potential as a marker for myocardial ischemiaa preliminary report. J Emerg Med 2000, 19:311-315.

87. Sinha MK, Roy D, Gaze DC, Collinson PO, Kaski JC: Role of 'ischemia modified albumin', a new biochemical marker of myocardial ischaemia, in the early diagnosis of acute coronary syndromes. Emerg Med J 2004, 21:29-34.

88. Refaai MA, Wright RW, Parvin CA, Gronowski AM, Scott MG, Eby CS: Ischemia-modified albumin increases after skeletal muscle ischemia during arthroscopic knee surgery. Clin Chim 
Acta 2006, 366:264-268.

89. Gaze DC, Crompton L, Collinson P: Ischemia-modified albumin concentrations should be interpreted with caution in patients with low serum albumin concentrations. Med Princ Pract 2006, 15:322-324.

90. Lippi G, Brocco G, Salvagno GL, Montagnana M, Dima F, Guidi GC: High-workload endurance training may increase serum ischemia-modified albumin concentrations. Clin Chem Lab Med 2005, 43:741-744.

91. Danne O, Mockel M, Lueders C, Mugge C, Zschunke GA, Lufft H, Muller C, Frei U: Prognostic implications of elevated whole blood choline levels in acute coronary syndromes. Am J Cardiol 2003, 91:1060-1067.

92. Danne O, Lueders C, Storm C, Frei U, Mockel M: Whole blood choline and plasma choline in acute coronary syndromes: prognostic and pathophysiological implications. Clin Chim Acta 2007, 383:103-109.

93. Schonbeck U, Mach F, Libby P: CD154 (CD40 ligand). Int J Biochem Cell Biol 2000, 32:687-693.

94. Stumpf C, Lehner C, Eskafi S, Raaz D, Yilmaz A, Ropers S Schmeisser A, Ludwig J, Daniel WG, Garlichs CD: Enhanced levels of CD154 (CD40 ligand) on platelets in patients with chronic heart failure. Eur J Heart Fail 2003, 5:629-637.

95. Varo N, de Lemos JA, Libby P, Morrow DA, Murphy SA, Nuzzo R, Gibson CM, Cannon CP, Braunwald E, Schonbeck U: Soluble CD40L: risk prediction after acute coronary syndromes. Circulation 2003, 108:1049-1052.

96. Nishikimi T, Miyata A, Horio T, Yoshihara F, Nagaya N, Takishita S, Yutani $\mathrm{C}$, Matsuo $\mathrm{H}$, Matsuoka $\mathrm{H}$, Kangawa K: Urocortin, a member of the corticotropin-releasing factor family, in normal and diseased heart. Am J Physio/ 2000, 279:Н3031-H3039.

97. Agnello D, Bertini R, Sacco S, Meazza C, Villa P, Ghezzi P: Corticosteroid-independent inhibition of tumor necrosis factor production by the neuropeptide urocortin. Am J Physiol 1998, 275:E757-E762.

98. Rademaker MT, Charles CJ, Espiner EA, Fisher S, Frampton CM, Kirkpatrick CM, Lainchbury JG, Nicholls MG, Richards AM, Vale WW: Beneficial hemodynamic, endocrine, and renal effects of urocortin in experimental heart failure: comparison with normal sheep. J Am Coll Cardiol 2002, 40:1495-1505.

99. Ng LL, Loke IW, O'Brien RJ, Squire IB, Davies JE: Plasma urocortin in human systolic heart failure. Clin Sci (Lond) 2004, 106:383-388

100. Tang WH, Brennan ML, Philip K, Tong W, Mann S, Van Lente F, Hazen SL: Plasma myeloperoxidase levels in patients with chronic heart failure. Am J Cardiol 2006, 98:796-799.

101. Tang WH, Tong W, Troughton RW, Martin MG, Shrestha K, Borowski A, Jasper S, Hazen SL, Klein AL: Prognostic value and echocardiographic determinants of plasma myeloperoxidase levels in chronic heart failure. J Am Coll Cardiol 2007, 49: 2364-2370.

102. Brennan ML, Penn MS, Van Lente F, Nambi V, Shishehbor MH, Aviles RJ, Goormastic M, Pepoy ML, McErlean ES, Topol EJ, Nissen SE, Hazen SL: Prognostic value of myeloperoxidase in patients with chest pain. N Engl J Med 2003, 349:1595-1604.

103. Stolker JM, Rich MW: The combination of B-type natriuretic peptide and C-reactive protein provides incremental prognostic value among older patients referred for cardiac catheterization. Am J Geriatr Cardiol 2007, 16:229-235.

104. Foussas SG, Zairis MN, Makrygiannis SS, Manousakis SJ, Anastassiadis FA, Apostolatos CS, Patsourakos NG, Glyptis MP, Papadopoulos JK, Xenos DC, Adamopoulou EN, Olympios CD, Argyrakis SK: The significance of circulating levels of both cardiac troponin I and high-sensitivity $C$ reactive protein for the prediction of intravenous thrombolysis outcome in patients with ST-segment elevation myocardial infarction. Heart 2007, 93:952-956.

105. Peacock F, Morris DL, Anwaruddin S, Christenson RH, Collinson PO, Goodacre SW, Januzzi JL, Jesse RL, Kaski JC, Kontos MC Lefevre G, Mutrie D, Sinha MK, Uettwiller-Geiger D, Pollack CV: Meta-analysis of ischemia-modified albumin to rule out acute coronary syndromes in the emergency department. Am Heart J 2006, 152:253-262.

106. Guest TM, Ramanathan AV, Tuteur PG, Schechtman KB, Ladenson $\mathrm{JH}$, Jaffe AS: Myocardial injury in critically ill patients. A frequently unrecognized complication. JAMA 1995, 273: 1945-1949.
107. Noble JS, Reid AM, Jordan LV, Glen AC, Davidson JA: Troponin I and myocardial injury in the ICU. Br J Anaesth 1999, 82:41-46.

108. King DA, Codish S, Novack V, Barski L, Almog Y: The role of cardiac troponin I as a prognosticator in critically ill medical patients: a prospective observational cohort study. Crit Care 2005, 9:R390-R395.

109. Ammann P, Maggiorini M, Bertel O, Haenseler E, Joller-Jemelka $\mathrm{HI}$, Oechslin E, Minder El, Rickli H, Fehr T: Troponin as a risk factor for mortality in critically ill patients without acute coronary syndromes. J Am Coll Cardiol 2003, 41:2004-2009.

110. Lim W, Qushmaq I, Cook DJ, Crowther MA, Heels-Ansdell D, Devereaux PJ: Elevated troponin and myocardial infarction in the intensive care unit: a prospective study. Crit Care 2005, 9: R636-R644.

111. Lim W, Cook DJ, Griffith LE, Crowther MA, Devereaux PJ: Elevated cardiac troponin levels in critically ill patients: prevalence, incidence, and outcomes. Am J Crit Care 2006, 15: 280-288.

112. Povoa P, Coelho L, Almeida E, Fernandes A, Mealha R, Moreira $P$, Sabino $\mathrm{H}$ : C-reactive protein as a marker of infection in critically ill patients. Clin Microbiol Infect 2005, 11:101-108.

113. Sierra R, Rello J, Bailen MA, Benitez E, Gordillo A, Leon C, Pedraza S: C-reactive protein used as an early indicator of infection in patients with systemic inflammatory response syndrome. Intensive Care Med 2004, 30:2038-2045.

114. Lobo SM, Lobo FR, Bota DP, Lopes-Ferreira F, Soliman HM, Melot C, Vincent JL: C-reactive protein levels correlate with mortality and organ failure in critically ill patients. Chest 2003 123:2043-2049 